\section{Modern management of psoriasis}

\section{Sharizan Abdul Ghaffar MRCP, Senior House Officer in Dermatology}

Suzanne E Clements MRCP, Senior House Officer in Dermatology

\section{Christopher EM Griffiths MD FRCP,}

Professor of Dermatology

The Dermatology Centre, University of Manchester, Hope Hospital, Salford, Manchester

\section{Clin Med 2005:5:564-8}

Psoriasis is a chronic inflammatory skin disorder which has a significant impact on patients' quality of life (QoL). Approximately 1.2 million people are affected in the UK, a large proportion of whom are dissatisfied with present treatments, and continuous use even of effective treatments can be limited by side effects. An understanding of the immunopathogenesis of psoriasis has given rise to targeted immune therapies known as 'biologics'. The four main biologics for this indication - alefacept, efalizumab, etanercept and infliximab are discussed in this article. It is important also to remember that psychological support is just as important as medical therapy in a chronic, currently incurable disease such as psoriasis.

The commonest form of psoriasis is the chronic plaque variety $(80 \%$ of cases), typically presenting as red, scaly plaques (Fig 1) on any skin surface but particularly on the extensor aspects of elbows and knees, scalp and lower back. Rarer forms of psoriasis include guttate, erythrodermic (Fig 2), pustular and flexural psoriasis. There is nail involvement in $50 \%$ of patients, often manifest as pitting, onycholysis, dystrophy or subungual hyperkeratosis (Fig 3), and inflammatory seronegative arthritis occurs in $10-15 \%$.

The first onset of psoriasis usually occurs before the age of 40 years with a second peak of incidence at 55-60 years. People with early onset psoriasis are more likely to have a strong family history of psoriasis $\left(65 \%\right.$ are $\left.\mathrm{HLA}-\mathrm{Cw} 6^{+}\right)$ than those with late onset disease. ${ }^{1}$
The significant impact on patients' QoL is frequently underestimated by medical professionals. It has been shown that impairment of QoL in patients with psoriasis is equivalent to or worse than other chronic medical conditions such as diabetes, asthma and cardiac insufficiency. $^{2}$ Psoriasis may be triggered or worsened by emotional stress, skin injury or trauma (Koebner phenomenon), viral/bacterial infections, HIV infection and drugs, including beta-blockers, non-steroidal anti-inflammatory drugs, antimalarials and lithium.

\section{Pathophysiology and immunology of psoriasis}

The classic histological features of psoriasis are epidermal keratinocyte proliferation and loss of differentiation, angiogenesis and an inflammatory infiltrate. There is compelling evidence that activated $\mathrm{T}$ cells are primary modulators in the pathogenesis of psoriasis and that activated $\mathrm{CD}_{45 \mathrm{RO}^{+}}$(memory-effector) $\mathrm{T}$ lymphocytes are present in plaques of psoriasis. In plaques, $\mathrm{CD}^{+} \mathrm{T}$ cells are

Fig 1 (below). Plaque psoriasis.

Fig 2 (right). Erythrodermic psoriasis.

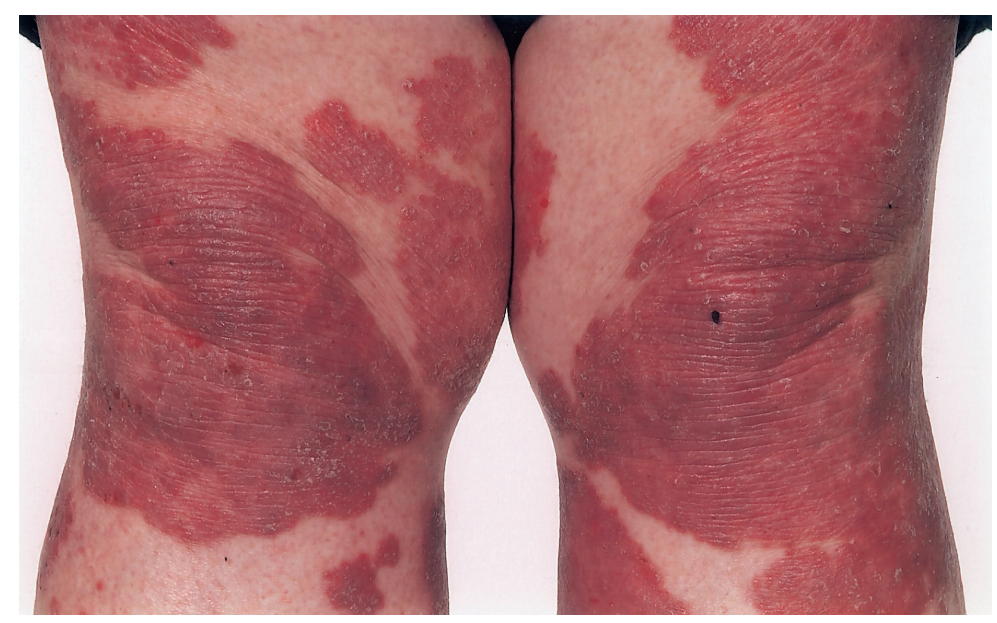

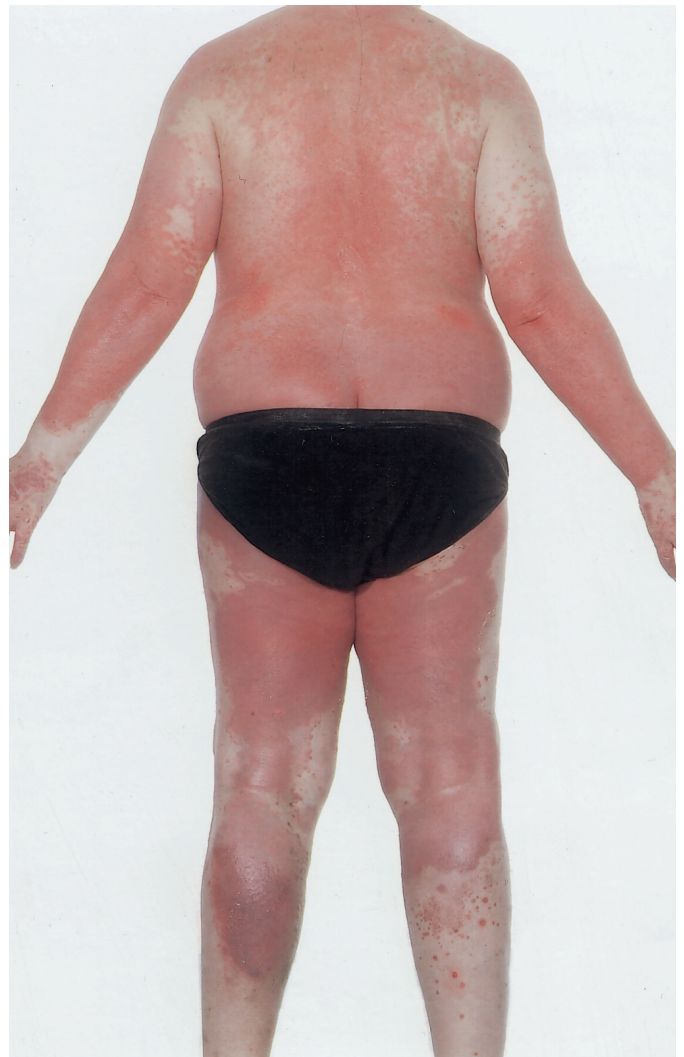


prevalent in the epidermis whereas $\mathrm{CD} 4^{+}$ $\mathrm{T}$ cells predominate in the dermis.

Cytokines released following $\mathrm{T}$ cell activation induce keratinocyte proliferation, stimulate the activity of additional $\mathrm{T}$ cells, increase vascularity and attract neutrophils - all key features of psoriasis. One of the key pro-inflammatory cytokines in psoriasis is tumour necrosis factor (TNF)- $\alpha$; a plaque of psoriasis is characterised by a predominance of T helper 1 cytokines including interferon (IFN)- $\gamma$ and interleukin (IL)-2. Leukocyte function-associated antigen (LFA)-1, a member of the leukocyte integrin family, is expressed on the surface of leukocytes. LFA-1 comprises a heterodimer of CD11a $(\alpha)$ and CD18 $(\beta)$ integrin subunits and plays an important role in $\mathrm{T}$ cell activation and leukocyte extravasation. CD11a binds to intercellular adhesion molecule (ICAM)-1, -2 and -3 on leukocytes, fibroblasts, endothelial cells and keratinocytes; expression of ICAM-1 is induced by a variety of cytokines, including IL-1, TNF- $\alpha$ and IFN- $\gamma$. These inflammatory events signal the migration and activation of $\mathrm{T}$ lymphocytes from the vasculature into and within the skin and are probably key to the pathogenesis of psoriasis. ${ }^{3}$

\section{Standard treatments}

There is currently no cure for psoriasis, so the primary aim of treatment is to provide symptomatic relief and safe long-term control of the disease. Three main forms of treatment for psoriasis are available (Table 1):

- topical

- phototherapy

- systemic.

However, there is a significant unmet need in the management of severe psoriasis as it is not possible at present to achieve clearance of disease without some degree of risk.

\section{Topical therapy}

Topical therapies, which include coal tar preparations, dithranol, vitamin D3 analogues, retinoids and corticosteroids, are generally the first-line of treatment for
Fig 3. Nail dystrophy and hyperkeratosis.

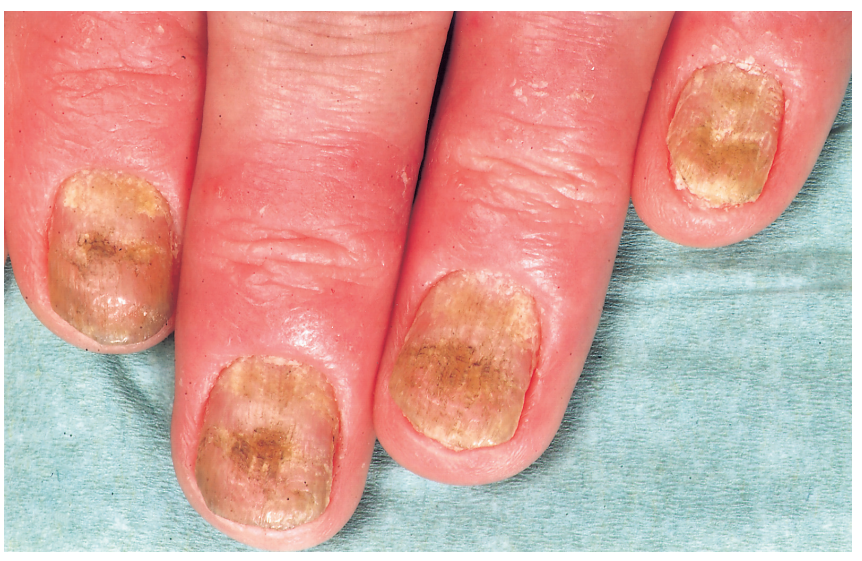

disease of limited extent. Topicals may also be used in combination with phototherapy or systemic agents for more severe cases, depending on clinical response. Most patients (75\%) with chronic plaque psoriasis can be treated satisfactorily with topical treatment alone. $^{1}$

\section{Phototherapy}

Phototherapy consists of either ultraviolet B (UVB) or oral or topical psoralens, followed by irradiation with long-wave ultraviolet A (PUVA). The principal unwanted side effects are 'sunburn' (which can be minimised by careful dosimetry), premature skin ageing and cutaneous malignancy when used over a long period. ${ }^{4}$

Ultraviolet $B$. UVB is increasingly used for the management of guttate or plaque psoriasis. Recently developed narrowband UVB (TL-O1) has a greater efficacy than traditional broad-band UVB. ${ }^{5}$ Patient compliance is usually good.

Ultraviolet A with oral or topical psoralen. PUVA is a well established form of psori-
Table 1. Summary of standard treatment options for psoriasis and their side effects. ${ }^{1}$

\begin{tabular}{|c|c|}
\hline Treatment & Side effects \\
\hline \multicolumn{2}{|l|}{ Topical therapy: } \\
\hline - Coal tar preparations & Strong smell, stains, skin irritation \\
\hline - Dithranol & Stains, skin irritation \\
\hline - Vitamin D3 analogues & Skin irritation, hypercalcaemia, reduction in vitamin D levels \\
\hline - Topical retinoids & Skin irritation and dryness \\
\hline - Topical corticosteroids & $\begin{array}{l}\text { Skin atrophy, telangiectasia, adrenal insufficiency (rare, only } \\
\text { with very potent steroids) }\end{array}$ \\
\hline \multicolumn{2}{|l|}{ Phototherapy: } \\
\hline - UVB & $\begin{array}{l}\text { Photodamage, increased risk of skin ageing and skin } \\
\text { cancers }\end{array}$ \\
\hline - $\quad$ PUVA & $\begin{array}{l}\text { Photodamage, increased risk of skin ageing and skin } \\
\text { cancers, ocular damage, acute effects (pruritus, nausea, } \\
\text { delayed sunburn-like erythema) }\end{array}$ \\
\hline \multicolumn{2}{|l|}{ Systemic therapy: } \\
\hline - Ciclosporin & Nephrotoxicity, hypertension, immunosuppression \\
\hline - Methotrexate & $\begin{array}{l}\text { Teratogenicity, myelosuppression, hepatotoxicity, pulmonary } \\
\text { fibrosis, acute effects (hypersensitivity, nausea, fatigue) }\end{array}$ \\
\hline - Acitretin & $\begin{array}{l}\text { Teratogenicity, hepatotoxicity, hyperlipidaemia, alopecia and } \\
\text { mucocutaneous toxicity }\end{array}$ \\
\hline - Hydroxycarbamide & $\begin{array}{l}\text { Myelosuppression, teratogenicity, gastrointestinal effects, } \\
\text { hyperpigmentation, renal dysfunction, oral and leg ulcers, } \\
\text { dermatomyositis-like skin changes }\end{array}$ \\
\hline
\end{tabular}

PUVA = psoralen with ultraviolet light $\mathrm{A} ; \mathrm{UVB}=$ ultraviolet light $\mathrm{B}$. 


\section{Key Points}

\section{Psoriasis is a chronic inflammatory skin condition which affects $2 \%$ of the population}

The impairment of quality of life in patients with psoriasis is significant

T cell activation plays an important role in the pathogenesis of psoriasis

Traditional systemic therapies are effective but continuous use can be limited by side effects

Biologics offer a new treatment option that targets specific stages of the inflammatory pathway

Psychological management is a useful adjunct to standard psoriasis treatments

KEY WORDS: biologics, immunology, psoriasis, psychology

asis treatment. Oral psoralen is associated with a theoretical risk of cataract formation. If nausea occurs, bath or topical psoralen can be used instead. ${ }^{6}$

\section{Systemic therapy}

The more frequently used systemic agents are methotrexate, ciclosporin and acitretin, but fumaric acid esters and hydroxycarbamide are sometimes used.

Methotrexate is an effective antipsoriatic agent that has been used for many years, ${ }^{7}$ often in acute, generalised pustular psoriasis, erythrodermic psoriasis, psoriatic arthritis and extensive chronic plaque psoriasis when topical therapy alone is inadequate. It can be given by the oral, intramuscular (im) or intravenous (iv) routes, usually as a single weekly dose, together with daily folic acid supplementation. Following stable full blood counts and liver function tests, patients can be maintained on a dose of 7.5-25 mg weekly. The most important potential side effect is acute marrow suppression (the cause of most of the relatively few deaths attributable to methotrexate). Patients need to avoid alcohol intake due to the increased risk of liver fibrosis. Measurement of serum levels of the $\mathrm{N}$-terminal peptide of type III procollagen, a serological marker of fibrosis, is now performed every three months; in many cases, this has reduced the need for liver biopsy. ${ }^{8}$
Ciclosporin is a rapidly acting and highly effective systemic treatment for psoriasis. ${ }^{9}$ The main side effects are renal impairment and hypertension, both of which are largely reversible. Blood pressure and renal function should be monitored fortnightly for eight weeks, then monthly or more frequently if there are concerns or dose changes. Ciclosporin is given in a dose of $2.5-5 \mathrm{mg} / \mathrm{kg} /$ day, usually as short-term, intermittent therapy to induce remission. Courses of treatment can be repeated following further relapse.

Acitretin is the treatment of choice for psoriasis. ${ }^{10}$ It can be used effectively as monotherapy or in combination, particularly with PUVA. It is associated with a number of (mainly subjective) side effects. Almost all patients will have mucocutaneous side effects such as drying and cracking of the lips and skin. There is a high risk of teratogenicity if administered during the first three months of pregnancy. Two forms of contraception and regular pregnancy tests are required during the course of treatment and pregnancy should be avoided for two years after stopping acitretin. Elevation of liver enzymes and plasma lipid levels may also occur.

\section{Biologics}

Safety limitations of traditional therapies have made it difficult to offer patients continuous safe clearance of psoriasis hence the need for additional treatment options, particularly for patients with moderate to severe disease. In a survey of members of the National Psoriasis Foundation in North America only 22\% of patients were satisfied with current treatments for severe psoriasis. ${ }^{11}$ Understanding of the pathogenesis of psoriasis has led to the development of new strategies to control the inflammatory process (ie 'biologics'). Several key points in the inflammatory pathway leading to psoriasis can be targeted by biologic agents (Table 2).

\section{Alefacept}

Alefacept (Amevive ${ }^{\text {TM}}$; Biogen-Idec) ${ }^{12}$ is a recombinant fusion protein comprising the terminal portion of LFA-3 and the Fc portion of immunoglobulin (Ig) G1. It binds to the $\mathrm{T}$ cell receptor $\mathrm{CD} 2$, and hence inhibits secondary $\mathrm{T}$ cell activation that follows binding to LFA-3 on antigen presenting cells. A secondary mechanism of action is via apoptosis of circulating $\mathrm{CD}_{45 \mathrm{RO}^{+}} \mathrm{T}$ cells dependent on granzyme release from natural killer cells. CD45RO ${ }^{+} \mathrm{T}$ cells are preferentially apoptosed as they express high levels of CD2. Alefacept is administered weekly by either iv or im fixed dose injection (7.5 $\mathrm{mg}$ or $15 \mathrm{mg}$, respectively) for a 12-week cycle.

The onset of improvement is slow, averaging eight weeks before any significant clinical improvement is obvious. A $75 \%$ reduction in the Psoriasis Area Severity Index (PASI) (a measure of clinical severity of psoriasis) is achieved in only $20 \%$ of patients by 12 weeks. Peripheral CD4 T cell counts should be monitored, but alefacept has been shown to be safe, certainly in the short term, and for up to 12 cycles of treatment.

\section{Efalizumab}

A humanised IgG1 monoclonal antibody, efalizumab (Raptiva ${ }^{\mathrm{TM}}$; Serono), ${ }^{13}$ directed against the CD11a subunit in LFA-1, blocks LFA-1 from binding ICAM-1. This then inhibits both $\mathrm{T}$ cell activation and adhesion of circulating $\mathrm{T}$ cells to ICAM-1-expressing endothelial 
cells and keratinocytes, thus preventing cutaneous $\mathrm{T}$ cell trafficking. Efalizumab is a self-administered, once weekly, $1 \mathrm{mg} / \mathrm{kg}$ subcutaneous (sc) injection.

Significant clinical improvement can be seen within two weeks of starting treatment, and $25 \%$ of patients achieve $75 \%$ reduction in PASI (PASI 75) by 12 weeks of treatment. However, the effect on psoriatic arthritis appears modest. Patients require monitoring of full blood count due to case reports of thrombocytopenia, but efalizumab has been used continuously and safely for up to three years.

\section{Etanercept}

Etanercept (Enbrel ${ }^{\mathrm{TM}}$; Wyeth/Amgen $)^{14}$ is a fully human recombinant fusion protein comprising the TNF- $\alpha$ p75 receptor fused to the Fc portion of the IgG1 molecule. It functions as a TNF- $\alpha$ inhibitor by binding to and inactivating TNF- $\alpha$, thereby preventing interactions with its cell surface receptors. Etanercept is self-administered by twice weekly sc injections, $25 \mathrm{mg}$ or $50 \mathrm{mg}$.

Onset of improvement occurs within 2-3 weeks. The response is good, with $34 \%$ of patients on $25 \mathrm{mg}$ and $49 \%$ of patients on $50 \mathrm{mg}$ achieving PASI 75 by week 12. It is effective also for psoriatic arthritis. Injection site reactions are common, but etanercept is well tolerated and continuous use for up to 24 weeks (for which it is licensed) has been shown to be safe.

\section{Infliximab}

A chimeric monoclonal antibody, infliximab (Remicade ${ }^{\mathrm{TM}}$; Schering-Plough/ Centocor), ${ }^{15}$ also binds to and inhibits the activity of TNF- $\alpha$. It is given as an iv infusion of $5 \mathrm{mg} / \mathrm{kg}$ body weight at baseline, two and six weeks, followed by repeat infusions at eight-weekly intervals depending on clinical activity. Infliximab has also been used to treat rheumatoid arthritis and Crohn's disease.

Infliximab works rapidly and effectively. Clinical improvement is seen at one week; over $80 \%$ of patients achieve PASI 75 by 10 weeks, with $60 \%$ already achieving this level within six weeks. Like etanercept, it is also effective for psoriatic arthritis. Infusion reactions are common although there is no good evidence that these are related to the development of antibodies.

All patients on anti-TNF- $\alpha$ therapy (etanercept and infliximab) should be screened for active and also old tuberculosis as there are case reports of reactivation especially with infliximab. Other, rarer, side effects of anti-TNF- $\alpha$ therapy include demyelination, cardiac failure, hepatitis, lymphoma and development of autoimmune antibodies, eg antinuclear antibodies (ANA) and anti-dsANA. At present, safety and efficacy data are available for up to 50 weeks.

\section{Cognitive behavioural therapy}

Research has shown that psychological stress may exacerbate and/or be a consequence of a range of immune-mediated diseases. Even low-grade, day-to-day stress, not just major stressful events, can have an effect on prognosis. ${ }^{16}$ Stress related to psoriasis is multifactorial. It may occur from:

- humiliation and depression associated with the stigma of visible plaques

- the time-consuming application of treatments

- forced unemployment in patients with incapacitating disease

- reduced self confidence.

Stress was found to be a self-reported trigger factor in up to $60 \%$ of patients with psoriasis, with higher scores on standardised assessments of stress than in the normal population. ${ }^{17}$ Cognitive behavioural approaches have pre-

Table 2. Summary table of biologics treatment. ${ }^{12-15,19}$

\begin{tabular}{|c|c|c|c|c|}
\hline & Alefacept & Efalizumab & Etanercept & Infliximab \\
\hline Mechanism of action & $\mathrm{T}$ cell targeting & $\mathrm{T}$ cell targeting & TNF- $\alpha$ inhibition & TNF- $\alpha$ inhibition \\
\hline Licensed for psoriasis in UK & No & Yes & Yes & Yes \\
\hline Method of administration & $\begin{array}{l}15 \mathrm{mg} \text { im (7.5 mg iv) } \\
\text { weekly for } 12 \text { weeks }\end{array}$ & $\begin{array}{l}\text { Initial dose } 0.7 \mathrm{mg} / \mathrm{kg} \text {, } \\
\text { then } 1 \mathrm{mg} / \mathrm{kg} \mathrm{sc} \text { weekly }\end{array}$ & $\begin{array}{l}25-50 \text { mg sc } \\
\text { twice weekly }\end{array}$ & $\begin{array}{l}5 \mathrm{mg} / \mathrm{kg} \text { iv at } 0, \\
2 \text { and } 6 \text { weeks, then } \\
\text { 8-weekly }\end{array}$ \\
\hline Onset of action & $6-8$ weeks & $2-3$ weeks & $2-3$ weeks & 1 week \\
\hline$\%$ of patients with PASI 75 & $20 \%$ after 12 weeks & $25 \%$ after 12 weeks & $\begin{array}{l}34 \% \text { with } 25 \mathrm{mg} \\
49 \% \text { with } 50 \mathrm{mg} \\
\text { at } 12 \text { weeks }\end{array}$ & $>80 \%$ at 10 weeks \\
\hline Effects on psoriatic arthritis & In phase II trials & Modest & Yes & Yes \\
\hline Efficacy as monotherapy & Yes & Yes & Yes & Yes \\
\hline Monitoring investigations & $\begin{array}{l}\text { Peripheral CD4 } \\
T \text { cell count }\end{array}$ & $\begin{array}{l}\text { Monthly FBC for } \\
\text { first } 3 \text { months, then } \\
\text { 3-monthly }\end{array}$ & $\begin{array}{l}\text { FBC, renal and LFTs } \\
\text { at } 3 \text { months, then } \\
6 \text {-monthly }\end{array}$ & $\begin{array}{l}\text { FBC, renal and LFTs at } \\
3 \text { months, then } \\
6 \text {-monthly }\end{array}$ \\
\hline $\begin{array}{l}\text { Safety and efficacy data for } \\
\text { long-term use }\end{array}$ & $\begin{array}{l}\text { Up to } 12,12 \text {-week } \\
\text { cycles }\end{array}$ & Up to 3 years & Up to 24 weeks & Up to 50 weeks \\
\hline
\end{tabular}

FBC = full blood count; im = intramuscular; iv = intravenous; LFT = liver function test; PASI = Psoriasis Area Severity Index; sc $=$ subcutaneous, TNF = tumour necrosis factor. 
viously been shown to be successful in patients with cancer and rheumatic diseases. Similar results were found for psoriasis in a study by Fortune et al ${ }^{18}$ in which 93 patients with psoriasis were allocated to receive either standard psoriasis treatment alone or to enter a Psoriasis Symptom Management Programme (PSMP) which included cognitive behavioural therapy and relaxation techniques as an adjunct to standard therapy. They were assessed at baseline, six weeks and six months. The 40 patients who had PSMP as an adjunct showed significantly greater reductions in their PASI score, in self-reported disability and in psychological distress at six weeks, with continued improvement at six months' follow-up, than the 53 patients receiving standard treatment alone.

The success of using adjunctive psychological interventions clearly suggests that the future of psoriasis management will probably include close liaison between dermatologists and psychologists as the next step towards improving patient care.

\section{Conclusions}

The care of patients with psoriasis has taken a significant move for the better. An understanding of immune mechanisms contributing to disease expression has led to the development of selective, and probably safer, long-term therapies in the form of biologics. ${ }^{19}$ At the same time, awareness that patients need to be treated as individuals with differing psychological needs has ushered in the biopsychosocial approach to management.

\section{References}

1 Griffiths CEM, Camp RDR, Barker JNWN. Psoriasis. In: Burns DA, Breathnach SM, Cox NH, Griffiths CEM (eds). Rook's textbook of dermatology, 7th edn. Oxford: Blackwell Sciences, 2004.

2 Finlay AY, Coles EC. The effect of severe psoriasis on the quality of life of 369 patients. Br J Dermatol 1995;132:236-44.

3 Griffiths CEM. The immunological basis of psoriasis. Review. J Eur Acad Dermatol Venereol 2003;17(Suppl 2):1-5.

4 Dootson G, Norris PG, Gibson CJ, Diffey BL. The practice of ultraviolet phototherapy in the United Kingdom. Br J Dermatol 1994;131:873-7.

5 Picot E, Meunier I, Picot-Debeze MC, Peyron JL, Meynardier J. Treatment of psoriasis with a 311-nm UVB lamp. $\mathrm{Br} J$ Dermatol 1992;127:509-12.

6 British Photodermatology Group guidelines for PUVA. Br J Dermatol 1994;130:246-55.

7 Roenigk HH Jr, Auerbach R, Maibach HI, Weinstein GD. Methotrexate in psoriasis: revised guidelines. Review. J Am Acad Dermatol 1988;19(1 Pt 1):145-56.

8 Boffa MJ, Smith A, Chalmers RG et al. The place of type III procollagen aminopeptide (PIIINP) measurement in the assessment of liver damage in methotrexate-treated psoriatic patients. Br J Dermatol 1995;133 (Suppl 45):16-17.

9 van Hooff JP, Leunissen KM, van der Staak W. Cyclosporin and psoriasis. Lancet 1985; i:335.

10 Geiger JM, Saurat JH. Acitretin and etretinate. How and when they should be used. Review. Dermatol Clin 1993;11:117-29.

11 Krueger G, Koo J, Lebwohl M, Menter A et al. The impact of psoriasis on quality of life: results of a 1998 National Psoriasis Foundation patient-membership survey. Arch Dermatol 2001;137:280-4.

12 Ellis CN, Krueger GG; Alefacept Clinical Study Group. Treatment of chronic plaque psoriasis by selective targeting of memory effector T lymphocytes. $N$ Engl $\mathrm{J} \mathrm{Med}$ 2001;345:248-55.

13 Gordon KB, Papp KA, Hamilton TK, Walicke PA et al. Efalizumab for patients with moderate to severe plaque psoriasis: a randomized controlled trial. JAMA 2003; 290:3073-80.

14 Leonardi CL, Powers JL, Matheson RT, Goffe BS et al. Etanercept as monotherapy in patients with psoriasis. $N$ Engl J Med 2003;349:2014-22.

15 Gottlieb AB, Evans R, Li S, Dooley LT et al. Infliximab induction therapy for patients with severe plaque-type psoriasis: a randomized, double-blind, placebo-controlled trial. J Am Acad Dermatol 2004;51:534-42.

16 Cohen S, Doyle WJ, Skoner DP. Psychological stress, cytokine production, and severity of upper respiratory illness. Psychosom Med 1999;61:175-80.

17 Harvima IT, Viinamaki H, Naukkarinen A, Paukkonen $\mathrm{K}$ et al. Association of cutaneous mast cells and sensory nerves with psychic stress in psoriasis. Psychother Psychosom 1993;60:168-76.

18 Fortune DG, Richards HL, Kirby B, Bowcock $\mathrm{S}$ et al. A cognitive-behavioural symptom management programme as an adjunct in psoriasis therapy. $\mathrm{Br} J$ Dermatol 2002;146:458-65.

19 Sterry W, Barker J, Boehncke W, Bos JD et al. Biological therapies in the systemic management of psoriasis: International Consensus Conference. Review. $\mathrm{Br} \mathrm{J}$ Dermatol 2004;151(Suppl 69):3-17. 